\title{
Risk factors for infection with multidrug-resistant bacteria in non-ventilated patients with hospital-acquired pneumonia ${ }^{*, * *}$
}

\author{
Fatores de risco para multirresistência bacteriana em pneumonias \\ adquiridas no hospital não associadas à ventilação mecânica
}

\author{
Renato Seligman, Luis Francisco Ramos-Lima, Vivian do Amaral Oliveira, \\ Carina Sanvicente, Juliana Sartori, Elyara Fiorin Pacheco
}

\begin{abstract}
Objective: To identify risk factors for the development of hospital-acquired pneumonia (HAP) caused by multidrugresistant (MDR) bacteria in non-ventilated patients. Methods: This was a retrospective observational cohort study conducted over a three-year period at a tertiary-care teaching hospital. We included only non-ventilated patients diagnosed with HAP and presenting with positive bacterial cultures. Categorical variables were compared with chi-square test. Logistic regression analysis was used to determine risk factors for HAP caused by MDR bacteria. Results: Of the 140 patients diagnosed with HAP, 59 (42.1\%) were infected with MDR strains. Among the patients infected with methicillin-resistant Staphylococcus aureus and those infected with methicillinsusceptible S. aureus, mortality was $45.9 \%$ and $50.0 \%$, respectively $(p=0.763)$. Among the patients infected with MDR and those infected with non-MDR gram-negative bacilli, mortality was $45.8 \%$ and $38.3 \%$, respectively ( $p=0.527)$. Univariate analysis identified the following risk factors for infection with MDR bacteria: COPD; congestive heart failure; chronic renal failure; dialysis; urinary catheterization; extrapulmonary infection; and use of antimicrobial therapy within the last 10 days before the diagnosis of HAP. Multivariate analysis showed that the use of antibiotics within the last 10 days before the diagnosis of HAP was the only independent predictor of infection with MDR bacteria $(\mathrm{OR}=3.45 ; 95 \% \mathrm{Cl}: 1.56-7.61 ; \mathrm{p}=0.002)$. Conclusions: In this single-center study, the use of broad-spectrum antibiotics within the last 10 days before the diagnosis of HAP was the only independent predictor of infection with MDR bacteria in non-ventilated patients with HAP.
\end{abstract}

Keywords: Pneumonia, bacterial; Drug resistance, bacterial; Cross infection.

\section{Resumo}

Objetivo: Identificar fatores de risco para o desenvolvimento de pneumonia adquirida no hospital (PAH), não associada à ventilação mecânica e causada por bactérias multirresistentes (MR). Métodos: Estudo de coorte observacional retrospectivo, conduzido ao longo de três anos em um hospital universitário terciário. Incluímos apenas pacientes sem ventilação mecânica, com diagnóstico de PAH e com cultura bacteriana positiva. Variáveis categóricas foram comparadas por meio do teste do qui-quadrado. A análise de regressão logística foi usada para determinar os fatores de risco para PAH causada por bactérias MR. Resultados: Dos 140 pacientes diagnosticados com PAH, 59 (42,1\%) apresentavam infecção por cepas MR. As taxas de mortalidade nos pacientes com cepas de Staphylococcus aureus resistentes e sensíveis à meticilina, respectivamente, foram de 45,9\% e 50,0\% ( $p=$ 0,763). As taxas de mortalidade nos pacientes com PAH causada por bacilos gram-negativos MR e não MR, respectivamente, foram de 45,8\% e 38,3\% ( $p=0,527)$. Na análise univariada, os fatores associados com cepas MR foram DPOC, insuficiência cardíaca crônica, insuficiência renal crônica, diálise, cateterismo urinário, infecções extrapulmonares e uso de antimicrobianos nos 10 dias anteriores ao diagnóstico de $\mathrm{PAH}$. Na análise multivariada, o uso de antimicrobianos nos 10 dias anteriores ao diagnóstico foi o único fator preditor independente de cepas MR (OR = 3,45; 1C95\%: 1,56-7,61; $p=0,002)$. Conclusões: Neste estudo unicêntrico, o uso de antimicrobianos de largo espectro 10 dias antes do diagnóstico de PAH foi o único preditor independente da presença de bactérias MR em pacientes com $\mathrm{PAH}$ sem ventilação mecânica.

Descritores: Pneumonia bacteriana; Farmacorresistência bacteriana; Infecção hospitalar.

\footnotetext{
* Study carried out at the Hospital de Clínicas de Porto Alegre, Porto Alegre, Brazil.

Correspondence to: Renato Seligman. Avenida Ramiro Barcelos, 2350, Hospital de Clínicas de Porto Alegre, CEP 90035-903, Porto Alegre, RS, Brasil. Tel. 5551 3359-8781. E-mail: reseligman@hcpa.ufrgs.br

Financial support: This study received financial support from the Fundo de Incentivo à Pesquisa (FIPE, Research Incentive Fund) of the Hospital de Clínicas de Porto Alegre.

Submitted: 22 May 2012. Accepted, after review: 14 March 2013.

**A versão completa em português deste artigo está disponível em www.jornaldepneumologia.com.br
} 


\section{Introduction}

Hospital-acquired pneumonia (HAP) represents the second major cause of nosocomial infection, accounting for approximately $15 \%$ of all hospitalassociated infections and supplanted only by urinary tract infection. ${ }^{(1)}$ However, HAP is associated with the highest mortality rate of all nosocomial infections. ${ }^{(2)}$ Mortality related to HAP is estimated to be between $33 \%$ and $50 \% .{ }^{(3)}$ The attributable costs for HAP are substantial because they are associated with prolonged hospital stay (by 4-9 days). ${ }^{(4)}$

As a rule, HAP results from microbial invasion of the normally sterile lung parenchyma. Most cases of nosocomial pneumonia are due to microaspiration of contaminated oropharyngeal or gastric secretions. A defect in normal host defenses (e.g., the use of endotracheal intubation), aspiration of a large inoculum of organisms, or aspiration of a particularly virulent organism might contribute to parenchymal infection. ${ }^{(2)}$

Common pathogens associated with HAP include aerobic gram-negative bacilli, such as Pseudomonas aeruginosa, Escherichia coli, Klebsiella pneumoniae, and Acinetobacter spp. Infections due to gram-positive cocci, such as Staphylococcus aureus, particularly methicillinresistant $S$. aureus (MRSA), have been rapidly emerging. Pneumonia due to $S$. aureus is more common in patients with diabetes mellitus and head trauma, as well as in those hospitalized in ICUs. ${ }^{(3)}$

The frequency of specific multidrug-resistant (MDR) pathogens causing HAP can vary according to the hospital, population of patients, exposure to antibiotics, and type of ICU patient. That frequency changes over time, emphasizing the need for timely, local surveillance data. ${ }^{(3)}$

The rates of HAP due to MDR pathogens have increased dramatically in hospitalized patients, especially in ICU and transplanted patients. ${ }^{(5)}$ Data on the mechanisms of antibiotic resistance for specific bacterial pathogens have provided new insights into the adaptability of such pathogens.

The most significant risk factor for HAP is mechanical ventilation. In fact, various authors use the terms "HAP" and "ventilator-associated pneumonia" (VAP) interchangeably. Intubation increases the risk of pneumonia considerably (6- to 21-fold)..1) Previous studies showed other risk factors for HAP (excluding those related to VAP), which emerged from multivariate analyses, including age $>70$ years, chronic lung disease, depressed consciousness, aspiration, chest surgery, use of intracranial pressure monitor, use of nasogastric tube, treatment with histamine type-2 receptor $\left(\mathrm{H}_{2}\right)$ blockers or antacids, patient transport from the $1 \mathrm{CU}$ for diagnostic or therapeutic procedures, previous antibiotic exposure (particularly to third-generation cephalosporins), hospitalization during the fall or winter seasons, use of paralytic agents, and underlying illness. ${ }^{(6,7)}$

In recent years, inadequate HAP treatment, in the vast majority of the cases, has been proven to be due to resistant gram-negative bacteria or MRSA (not considered in the initial empirical regimen), and, since then, therapeutic decision making has not been relying solely on the time of the onset of pneumonia and previous antibiotic use. In the presence of comorbidities, recent use of antibiotics, or in institutionalized patients, the possibility of etiology by MDR germs becomes higher; therefore, the presence of risk factors for MDR germs serves as a basis for the decision making in order to draw up an adequate treatment regimen. ${ }^{(8)}$

Based on these concerns, the aim of the present study was to identify risk factors for the development of HAP caused by MDR bacteria in non-ventilated patients at a tertiary care teaching hospital.

\section{Methods}

This was a retrospective observational cohort study, conducted at the Hospital de Clínicas de Porto Alegre (HCPA), a 780-bed tertiary-care teaching hospital. All patients with a diagnosis of HAP and positive microbiological cultures admitted to HCPA between January of 2007 and December of 2009 were included in the study. All of the patients included were aged $>12$ years. Patients with HAP with negative microbiological cultures or those diagnosed with VAP were excluded.

The diagnosis of HAP was suspected only when pneumonia symptoms appeared at least $48 \mathrm{~h}$ after admission. The diagnosis of pneumonia was established when a patient developed a new and persistent radiographic infiltrate plus two of the following criteria: body temperature $\geq 38.0^{\circ} \mathrm{C}$ or $<36.0^{\circ} \mathrm{C}$; white blood cell count $>11,000$ cells $/ \mathrm{mm}^{3}$ or $<4,000$ cells $/ \mathrm{mm}^{3}$; and purulent sputum. ${ }^{(3)}$ 
The data collected included age, sex, comorbidities (including COPD, congestive heart failure, chronic renal failure, and malignancy), smoking status, immunosuppression, use of $\mathrm{H}_{2}$ antagonists, use of proton pump inhibitors, use of corticosteroids, use of nasogastric tube, use of a nasogastric feeding tube, dialysis, central vein catheterization, urinary tract catheterization, prophylactic antimicrobial therapy, antimicrobial therapy within the last 10 days before HAP diagnosis, and extrapulmonary infection. The data were collected from standard medical records and compiled into a structured questionnaire. The patients were considered immunosuppressed when chemotherapy was administered within the last 45 days prior to admission, when corticosteroids were used in immunosuppressive doses (prednisone $\geq 1 \mathrm{mg} / \mathrm{kg}$ per day or equivalent), or when the patient presented with neutropenia $(<1,000$ cells $/ \mathrm{mm}^{3}$ ).

Antimicrobial treatment was considered adequate on the basis of microbiological results. Adequate antibiotic therapy was defined as the coverage of all of the pathogens isolated from sputum, blood, or pleural fluid cultures by at least one antimicrobial agent administered for HAP, which was determined by the sensitivity pattern in the antibiogram.

The following pathogens were considered MDR on the basis of the knowledge available during the study period: MRSA; extendedspectrum $\beta$-lactamase-producing gram-negative Enterobacteriaceae, such as Klebsiella spp., E. coli, and Proteus spp.; P. aeruginosa resistant to ceftazidime or carbapenems; other pan-resistant Enterobacteriaceae bacteria or those sensitive only to carbapenems; sulfonamide-resistant Stenotrophomonas spp.; Acinetobacter spp. resistant to ampicillin, ampicillin/sulbactam, or carbapenems; and vancomycin-resistant Enterococcus spp. Other organisms were considered MDR if they were found to be resistant to at least three of the following antibiotic classes: antipseudomonal cephalosporins/penicillins, macrolides, carbapenems, fluoroquinolones, and aminoglycosides.

In 2005, the HCPA Infection Control Commission registered 142 cases of suspected HAP, and 93 cases had positive cultures. Considering a possible frequency of multidrug resistance of $20 \%$ in the group who received prior antibiotic treatment and of 5\% in the group who did not receive antibiotic treatment, a sample of 140 cases could show significant differences between the two groups adopting a significance level of $p=0.05$ and a power of $(1-\beta)=80 \%$. That sample size could be obtained by the search of cases during 18 consecutive months.

The selection of the cases was based on positive bacteriological test results. All of the cases with positive cultures were screened for HAP and described in the hospital medical records. The sputum processing protocol included a pre-analysis in order to validate the gram sample. Sputum samples were considered valid when direct examination revealed fewer than 10 epithelial cells and more than 25 polymorphonuclear cells at low magnification $(\times 100)$. The cultures were valued only when they were consistent with the findings of the direct examination. Cultures were qualitatively processed in the Microbiology Unit of HCPA Department of Clinical Pathology as part of a routine standard of care. Gram results were available in the electronic medical records within $4 \mathrm{~h}$ after sample collection, as were culture results within $72 \mathrm{~h}$ after the collection. All of the patients hospitalized for community-acquired pneumonia were excluded from the study.

Categorical variables were compared in the univariate analysis using the chi-square test. For those analyses, two-tailed tests and $p \leq$ 0.05 were considered statistically significant. Logistic regression analysis was used in order to determine the relationship between the risk factors and infection with MDR bacteria in the multivariate analysis. Variables with $\mathrm{p} \leq 0.15$ were considered significant and were entered into the multivariate model. In the multivariate model, variables with $p \leq 0.05$ were considered significant. The statistical analyses were performed with the Statistical Package for the Social Sciences for Windows, version 17.0 (SPSS Inc., Chicago, IL, USA).

Continuous variables are presented as means and standard deviations, whereas categorical variables are presented as absolute and relative frequencies. For the comparison of continuous variables, the Mann-Whitney $U$ test and the Student's t-test were used depending on variable distribution. For categorical variables, the Pearson chi-square test or the Fisher's exact test was used, as appropriate. Comparisons were made between the groups of patients infected with MDR strains and those infected with non-MDR strains. 
The present study was approved by the HCPA Research Ethics Committee, which, considering the nature of the study, waived requirements for informed consent.

\section{Results}

During the study period, 529 patients were diagnosed with HAP; 389 patients were excluded because the culture was negative, the culture was found to grow only fungi, or the diagnosis was VAP. The epidemiological characteristics and the clinical status of the 140 patients on admission, as well as the clinical findings at the time of diagnosis, are shown in Table 1.
Of the 140 patients with HAP, 59 (42.1\%) were infected with MDR bacteria, whereas 81 (57.9\%) were free of MDR strains. There was no significant difference in mortality between the groups infected with MDR and non-MDR bacteria $(p=0.519)$. According to the univariate analysis, the factors associated with the presence of MDR bacteria in sputum or blood cultures were renal failure, use of urinary catheter, and use of antibiotics within the last 10 days before the diagnosis of HAP.

Of the 140 patients, 52 were infected by $S$. aureus, $38(64.4 \%)$ of whom were infected by MRSA (Table 2); however, the presence of the MRSA phenotype was not a significant determinant of

Table 1 - Baseline characteristics of the patients who developed hospital-acquired pneumonia $(n=140) .{ }^{\text {a }}$

\begin{tabular}{|c|c|c|c|}
\hline \multirow[t]{3}{*}{ Variable } & \multicolumn{2}{|c|}{ Patients with HAP caused by } & \multirow[t]{3}{*}{$\mathrm{p}$} \\
\hline & MDR bacteria & Non-MDR bacteria & \\
\hline & $(n=59)$ & $(\mathrm{n}=81)$ & \\
\hline Age, years ${ }^{b}$ & $63 \pm 15$ & $63 \pm 14$ & 0.931 \\
\hline Male gender & $42(71.2)$ & $56(69.1)$ & 0.794 \\
\hline Type of hospitalization & & & 0.677 \\
\hline Clinical & $42(71.2)$ & $55(67.9)$ & \\
\hline Surgical & $17(28.8)$ & $26(32.1)$ & \\
\hline Previous comorbidities & $46(78.0)$ & $63(77.8)$ & 0.979 \\
\hline COPD & $21(35.6)$ & $19(23.5)$ & 0.117 \\
\hline Congestive heart failure & $12(20.3)$ & $8(9.9)$ & 0.081 \\
\hline Renal failure & $19(32.2)$ & $13(16.0)$ & 0.041 \\
\hline Malignant neoplasia & $27(45.8)$ & $46(56.8)$ & 0.197 \\
\hline Immunosuppression & $14(25.0)$ & $23(29.1)$ & 0.598 \\
\hline Extrapulmonary infection & $26(44.8)$ & $24(30.0)$ & 0.074 \\
\hline Smokers & $21(35.6)$ & $31(38.3)$ & 0.746 \\
\hline \multicolumn{4}{|l|}{ Previous use of medication } \\
\hline Corticosteroid therapy & $22(37.3)$ & $36(44.4)$ & 0.396 \\
\hline $\mathrm{H}_{2}$ receptor antagonists & $21(35.6)$ & $29(35.8)$ & 0.980 \\
\hline Proton pump inhibitors & 33 (55.9) & $47(58.0)$ & 0.805 \\
\hline \multicolumn{4}{|l|}{ Invasive procedures } \\
\hline Tracheostomy & $3(5.1)$ & $6(7.4)$ & 0.580 \\
\hline Dialysis & $9(15.3)$ & $5(6.2)$ & 0.077 \\
\hline Central catheter & 22 (37.3) & $29(35.8)$ & 0.857 \\
\hline Urinary catheter & $38(64.4)$ & 38 (46.9) & 0.040 \\
\hline Nasogastric intubation & $6(10.2)$ & $8(9.9)$ & 0.955 \\
\hline Nasogastric feeding tube use & $32(54.2)$ & $36(44.4)$ & 0.252 \\
\hline Septic status & & & 0.469 \\
\hline Sepsis & $16(27.1)$ & $15(18.5)$ & \\
\hline Septic shock & $4(6.8)$ & $7(8.6)$ & \\
\hline Use of antibiotics within 10 days prior to diagnosis & $45(76.3)$ & $38(46.9)$ & 0.001 \\
\hline Prophylactic antibiotic therapy & $4(6.8)$ & $6(7.4)$ & 0.887 \\
\hline Mortality during hospitalization & $28(47.5)$ & $34(42.0)$ & 0.519 \\
\hline
\end{tabular}

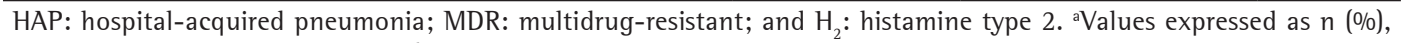
except where otherwise indicated. ${ }^{b}$ Values expressed as mean \pm SD. 
a difference in mortality: 17 of the 37 patients with MRSA-related HAP died (45,9\%), whereas 11 of the 22 with non-MRSA-related HAP died $(50 \% ; p=0.763)$.

Of the 140 patients, 84 had HAP caused by gram-negative bacilli, as a single type of germ or polymicrobial infection; however, the presence of MDR strains was not a significant determinant of a difference in mortality. Of the 24 patients with HAP related to MDR strains, 11 $(45.8 \%)$ died, whereas, of the 60 patients with HAP caused by non-MDR strains, 23 (38.3\%) died $(p=0.527)$.

In the multivariate analysis, we added four variables (respecting the limit of $p \leq 0.15$ ), to those included in the univariate analysis (i.e., presence of renal failure, use of urinary catheter, and antibiotic therapy within the last 10 days prior to HAP diagnosis): presence of extrapulmonary infections, dialysis, previous history of COPD, and previous history of congestive heart failure (Table 3). In the multivariate analysis, antibiotic therapy within the last 10 days prior to HAP diagnosis was the only independent predictor of infection with MDR bacteria (OR $=3.45 ; 95 \%$ $\mathrm{Cl}: 1.56-7.61 ; p=0.002)$.

The pattern of resistance in the isolates was as follows: penicillins, in $42.2 \%$ of the isolates; cephalosporins, in 33.3\%; quinolones, in 26.7\%; carbapenems, in 8.9\%; and aminoglycosides, in 2.2\%. Regarding the antibiotic therapy for MDR bacteria in HAP, $15.6 \%$ and $24.4 \%$ of the strains, respectively, were resistant to ampicillin/ sulbactam and to ciprofloxacin. The resistance rates in the patients with previous antibiotic use within the last 10 days prior to HAP diagnosis are shown in Table 4.

\section{Discussion}

In the present single-center study, the use of broad-spectrum antibiotics within the last 10 days before the diagnosis of HAP was the only independent predictor for HAP caused by MDR bacteria. Chronic renal failure and urinary tract catheterization were risk factors for this outcome only in the univariate analysis.

These results are in accordance with those in other studies, which described previous antibiotic therapy as a risk factor for HAP. ${ }^{(9-11)}$ However, in our cohort, age $>70$ years, chest surgery, use of nasogastric tube, and $\mathrm{H}_{2}$ blocker therapy were not independent predictors.

S. aureus and gram-negative microorganisms were the most common etiologic agents in our sample (80.0\%). Typical hospital-acquired bacteria were identified in 125 patients (89.3\%), whereas 15 (10.7\%) presented with common communityacquired microorganisms. Prolonged hospital stay and early colonization of respiratory tract with nosocomial flora could explain these results. ${ }^{(10,12)}$

The predisposition of $S$. aureus and gramnegative pathogens to develop antibiotic resistance has been demonstrated. Rello et al. ${ }^{(12)}$ observed it when comparing the patients with VAP caused by MRSA and those with VAP caused by methicillin-

Table 2 - Microbiological identification in hospital-acquired pneumonia patients $(\mathrm{n}=140){ }^{\text {a }}$

\begin{tabular}{lccc}
\hline & \multicolumn{2}{c}{ Microorganism $^{\mathrm{b}}$} & \multicolumn{2}{c}{ Total } \\
\cline { 2 - 3 } & MDR bacteria & Non-MDR bacteria & \\
\cline { 2 - 3 } & $\mathrm{n}=59)$ & $\mathrm{n}=81)$ & $\mathrm{n}=140)$ \\
\hline Staphylococcus aureus & $38(64.4)$ & $14(17.3)$ & $18(12.9)$ \\
Enterobacter sp. & $8(13.6)$ & $9(12.3)$ & $16(11.4)$ \\
Klebsiella pneumoniae & $7(11.9)$ & $12(14.8)$ & $14(10.0)$ \\
Pseudomonas aeruginosa & $2(3.4)$ & $10(12.3)$ & $12(8.6)$ \\
Escherichia coli & $2(3.4)$ & $12(14.8)$ & $12(8.6)$ \\
Haemophilus sp. & $0(0.0)$ & $3(3.7)$ & $8(5.7)$ \\
Acinetobacter sp. & $5(8.5)$ & $6(4.9)$ & $7(5.0)$ \\
Coagulase-negative Staphylococcus sp. & $1(1.7)$ & $5(6.2)$ & $5(3.6)$ \\
Enterococcus sp. & $0(0.0)$ & $0(0.0)$ & $2(1.4)$ \\
Acinetobacter baumannii & $2(3.4)$ & $17(21.0)$ & $17(12.1)$ \\
Other & $0(0.0)$ &
\end{tabular}

HAP: hospital-acquired pneumonia; and MDR: multidrug-resistant. ${ }^{a}$ Values expressed as $n(\%) .{ }^{\text {bWe identified more }}$ than one microorganism in 23 patients (13 patients with MDR bacteria and 10 patients with non-MDR bacteria). 'Stenotrophomonas maltophilia, Streptococcus pneumoniae, Citrobacter freundii, Proteus mirabilis, Streptococcus viridans, Citrobacter koseri, Klebsiella oxytoca, Providencia rettgeri, Serratia sp., and Moraxella sp. 
Table 3 - Risk factors for multidrug-resistant bacteria in hospital-acquired pneumonia.*

\begin{tabular}{lcccc}
\hline \multicolumn{1}{c}{ Variable } & $\beta$ & $\operatorname{Exp}(\beta)$ OR & Cl 95\% OR & $\mathrm{p}$ \\
\hline Intercept & -2.264 & & & 0.008 \\
COPD & 0.864 & 2.374 & $(0.982-5.740)$ & 0.055 \\
Congestive heart failure & 0.231 & 1.260 & $(0.404-3.931)$ & 0.691 \\
Renal failure & 0.603 & 1.828 & $(0.580-5.759)$ & 0.303 \\
Extrapulmonary infection & 0.438 & 1.550 & $(0.699-3.440)$ & 0.281 \\
Dialysis & 0.486 & 1.625 & $(0.367-7.203)$ & 0.523 \\
Urinary catheter & 0.322 & 1.379 & $(0.618-3.078)$ & 0.432 \\
Use of antibiotics within 10 days prior to diagnosis & 1.237 & 3.447 & $(1.561-7.610)$ & 0.002
\end{tabular}

${ }^{*}$ Multivariate analysis.

Table 4 - Resistance rates in 83 patients with previous antibiotic use within 10 days prior to the diagnosis of hospital-acquired pneumonia. ${ }^{a}$

\begin{tabular}{lccc}
\hline & \multicolumn{2}{c}{ Patients with HAP caused by } & \\
\cline { 2 - 3 } & MDR bacteria & Non-MDR bacteria \\
\cline { 2 - 3 } & $(\mathrm{n}=45)$ & $(\mathrm{n}=38)$ & \\
\hline Penicillins & $19(42.2)$ & $16(42.1)$ & 0.991 \\
$\quad$ Amoxicillin/clavulanate & $6(13.3)$ & $3(7.9)$ & 0.427 \\
Ampicillin & $4(8.9)$ & $6(15.8)$ & 0.336 \\
Ampicillin/sulbactam & $7(15.6)$ & $1(2.6)$ & 0.047 \\
Oxacillin & $1(2.2)$ & $2(5.3)$ & 0.460 \\
Penicillin & 0 & $2(5.3)$ & 0.119 \\
Piperacillin/tazobactam & $4(8.9)$ & $3(7.9)$ & 0.871 \\
Cephalosporins & $15(33.3)$ & $8(21.1)$ & 0.213 \\
Cefazolin & $2(4.4)$ & $0(0.0)$ & 0.188 \\
Cephalexin & $0(0.0)$ & $1(2.6)$ & 0.274 \\
Cefoxitin & $0(0.0)$ & $1(2.6)$ & 0.274 \\
Cefuroxime & $7(15.6)$ & $4(10.5)$ & 0.501 \\
Cefepime & $7(15.6)$ & $2(5.3)$ & 0.133 \\
Carbapenems & $4(8.9)$ & $5(13.2)$ & 0.533 \\
Imipenem & $3(6.7)$ & $4(10.5)$ & 0.113 \\
$\quad$ Meropenem & $1(2.2)$ & $1(2.6)$ & 0.904 \\
Quinolones & $12(26.7)$ & $6(15.8)$ & 0.231 \\
$\quad$ Ciprofloxacin & $11(24.4)$ & $4(10.5)$ & 0.101 \\
Norfloxacin & $2(4.4)$ & $2(5.3)$ & 0.862 \\
Aminoglycosides: gentamicin & $1(2.2)$ & $3(7.9)$ & 0.229 \\
Tetracyclines: doxycycline & $0(0.0)$ & $1(2.6)$ & 0.274 \\
Macrolides: azithromycin & $3(6.7)$ & $0(0.0)$ & 0.105 \\
Sulfonamides: sulfamethoxazole/trimethoprim & $3(6.7)$ & $4(10.5)$ & 0.528 \\
Chloramphenicol & $0(0.0)$ & $1(2.6)$ & 0.274 \\
Clindamycin & $5(11.1)$ & $5(13.2)$ & 0.775 \\
Vancomycin & $5(11.1)$ & $6(15.8)$ & 0.531 \\
Metronidazole & $6(13.3)$ & $2(5.3)$ & 0.215 \\
\hline
\end{tabular}

HAP: hospital-acquired pneumonia; and MDR: multidrug-resistant. aValues expressed as $n(\%)$.

susceptible S. aureus, $100 \%$ and $21 \%$, respectively, having received antibiotics a few days prior to the onset of the infection. Similar results were reported by Trouillet et al., ${ }^{(10)}$ who showed that prolonged hospital stay and prior antimicrobial treatment were risk factors for MRSA pneumonia.
The high rate of resistance to oxacillin corroborates the guidelines established by a Brazilian consensus on pneumonia, ${ }^{(13)}$ whereby all S. aureus strains should be considered resistant to oxacillin for the purposes of designing empirical treatment regimens for nosocomial pneumonia, 
especially in cases related to mechanical ventilation. In an elegant study designed to compare quantitatively the results of BAL fluid cultures with those of cultures from postmortem lung biopsy samples, Balthazar et al. ${ }^{(14)}$ also found $S$. aureus to be the most common causative agent. Data from one surveillance program in Brazil, ${ }^{(15)}$ however, revealed that, in samples collected in various Brazilian hospitals, S. aureus was the second most prevalent microorganism (19.6\%), and that approximately half of the strains was MRSA. Carrilho ${ }^{(16)}$ also demonstrated that $S$. aureus was the second most common germ in nosocomial pneumonia in the ICU of a university hospital in the north of the state of Paraná. Korn et al. ${ }^{(17)}$ studied 100 patients admitted to two ICUs and reported that, at the time of admission, 46 were colonized by MRSA, and, after admission, 28 became colonized with the same type of germ, and 16 developed respiratory or urinary infections. The authors found no risk factors in their sample but called attention to the fact that 20\% of the patients colonized with MRSA at admission had not been previously admitted to the ICU and had not been transferred from another hospital ward.

In our sample, the exposure to ampicillin/ sulbactam significantly increased the risk for MDR bacterial infections -7 cases $(15.6 \%)$ vs. 1 $(2.6 \% ; p=0.047)$-but the use of carbapenems in 9 patients did not demonstrate a trend towards that risk ( $p=0.533$ ). Surprisingly, the use of carbapenems did not increase the number of MDR cases, and we attribute that to the small number of patients who used these antimicrobials in our sample.

Even though the use of quinolones doubled the frequency of MDR bacterial infection-12 cases $(26.7 \%)$ vs. $6(15.8 \%)$-no statistical significance was found ( $p=0.231$ ), possibly because of the small number of specific cases. The limited use of quinolones in hospitalized patients is a preventive measure of the infection surveillance and control committee in our hospital.

Our findings are in accordance with the results of Trouillet et al., who suggested that receiving any fluoroquinolone might be a risk factor for acquiring piperacillin-resistant $P$. aeruginosa. ${ }^{(18)}$ Carmeli et al. also found that previous treatment with ciprofloxacin was a risk factor of the emergence of antibiotic-resistant $P$. aeruginosa. ${ }^{(19)}$
Harris et al. found that the exposure to piperacillin/tazobactam was the major factor that predisposes to the development of infections with MDR $P$. aeruginosa. The previous exposure to piperacillin/tazobactam was significantly associated with the isolation of piperacillin/tazobactamresistant $P$. aeruginosa $(\mathrm{OR}=8.63 ; 95 \% \mathrm{Cl}$ : 6.11-12.20; $p<0.0001) .{ }^{(20)}$

In addition to being intrinsically resistant to various antimicrobial agents, $P$. aeruginosa often develops resistance mechanisms to other antibiotics. This increasing antibiotic resistance makes the treatment of pneumonia caused by $P$. aeruginosa more difficult and more expensive. ${ }^{(21)}$ The emergence of VAP episodes caused by ureido/carboxypenicillin-resistant $P$. aeruginosa was significantly associated with the administration of broad-spectrum antimicrobials, such as ureidopenicillins, carboxypenicillins, or fluoroquinolones, at admission to the ICU. (21) Pneumonias caused by metallo- $\beta$-lactamaseproducing $P$. aeruginosa result in higher mortality rates. These emerging enzymes hydrolyze virtually all $\beta$-lactams. ${ }^{(22)}$

Based on the results from a surveillance program, ${ }^{(15)} P$. aeruginosa remains the most common type of germ that causes HAP/VAP. These data demonstrate the variability across hospitals and wards, as well as the risk of inadequate treatment by adopting prevalence data from different locations as a basis for the development of empiric treatment protocols. ${ }^{(8)}$

Besides $S$. aureus strains that are resistant to fluoroquinolones, aminoglycosides, and oxacillin, enterococci increased in importance, and the emergence of strains resistant to penicillin, aminoglycosides, and vancomycin has been described in various North American hospitals and, more recently, in Brazil. ${ }^{(23)}$ In our study, no MDR enterococci have been found.

The duration of exposure to these antibiotics should also be considered. In a case-control study conducted by Paramythiotou et al., among 34 patients infected with MDR $P$. aeruginosa, a previous treatment with ciprofloxacin or imipenem was a significant risk factor for the acquisition of MDR strains only when the duration of the treatment was longer than the median duration of treatment with those antimicrobials. ${ }^{(24)}$

Antibiotic use, or even overuse, can promote the emergence of resistant bacteria. The administration of combined broad-spectrum antibiotic therapy 
can lead to increased mortality in uninfected patients. ${ }^{(25)}$ When a hospital-acquired infection is diagnosed, broad-spectrum antibiotic therapy is often prescribed, usually prior to the availability of microbiological test results because of the possibility of a MDR germ being the etiologic agent. Previous antibiotic use was found to be an independent risk factor for VAP in one study. (26) The etiology of VAP in that population was associated with a high risk of germs resistant to antibiotics. Early and appropriate antimicrobial treatment must be assured. Consequently, the de-escalation of such treatment is the next step, but it is important to achieve the clinical cure in order to avoid persistent MDR microorganisms. The duration of the treatment must be assessed. Observational studies have suggested that early use of broad-spectrum antimicrobials and subsequent de-escalation after microbiological culture results might minimize the emergence of MDR $\operatorname{organisms}^{(10,27)}$ and reduce the costs ${ }^{(27)}$ during the treatment of patients with HAP. This strategy was associated with higher antimicrobial adequacy and more favorable outcomes, ${ }^{(28)}$ reducing the overall duration of antimicrobial treatment ${ }^{(29)}$ and mortality rates. ${ }^{(30)}$

Our study has some limitations. First, we used a retrospective design, and the patients included in the study were not assisted by the research team; we selected patients with positive cultures for aerobic pathogens, and patients who developed HAP but had negative cultures were excluded. Negative results could be a consequence of previous antimicrobial treatment. Second, we did not obtain results from BAL fluid cultures, but only from sputum cultures. Finally, our sample size was adequate to stratify the presence or the absence of MDR bacteria, but it was too small to allow the analysis of the risks implicated in the use of different individual antimicrobial agents.

Among hospital-acquired infections, HAP is the leading cause of death. It can be caused by a wide variety of pathogens, it can be polymicrobial, and it might be due to MDR pathogens. The frequency of MDR bacteria as etiologic agents in HAP is increasing, especially among patients with certain risk factors, such as recent antibiotic therapy, long-term hospitalization, and high frequency of antibiotic resistance in the specific hospital unit.

Regarding HAP prevention bundles, they involve the implementation of various procedures in an attempt to reduce the incidence of HAP among patients at risk, including educational programs, technical measures, surveillance, and feedback. In our study, the use of broad-spectrum antibiotics within the last 10 days before HAP diagnosis was the only independent predictor for infection with MDR bacteria in HAP. This finding is consistent with the Brazilian guidelines for the treatment of HAP and VAP, which state that the prior use of antibiotics in the 15 days preceding the disease is an important risk factor for potentially resistant pathogens. ${ }^{(8)}$

The development of infection control policies and procedures, with hospital-wide surveillance, as well as the review of antibiotic utilization and its relationship to local antibiotic resistance patterns, together with the development of guidelines for the rational use of antimicrobial therapy, are recommended.

\section{References}

1. Guidelines for prevention of nosocomial pneumonia. Centers for Disease Control and Prevention. MMWR Recomm Rep. 1997;46(RR-1):1-79. 2.

2. Flanders SA, Collard HR, Saint S. Nosocomial pneumonia: state of the science. Am J Infect Control. 2006;34(2):8493. http://dx.doi.org/10.1016/j.ajic.2005.07.003 PMid:16490612

3. American Thoracic Society; Infectious Diseases Society of America. Guidelines for the management of adults with hospital-acquired, ventilator-associated, and healthcare-associated pneumonia. Am J Respir Crit Care Med. 2005;171(4):388-416. http://dx.doi.org/10.1164/ rccm.200405-644ST PMid:15699079

4. Rotstein C, Evans G, Born A, Grossman R, Light RB, Magder $\mathrm{S}$, et al. Clinical practice guidelines for hospital-acquired pneumonia and ventilator-associated pneumonia in adults. Can J Infect Dis Med Microbiol. 2008;19(1):1953. PMid:19145262 PMCid:2610276

5. Richards MJ, Edwards JR, Culver DH, Gaynes RP. Nosocomial infections in medical intensive care units in the United States. National Nosocomial Infections Surveillance System. Crit Care Med. 1999;27(5):887-92. http://dx.doi.org/10.1097/00003246-199905000-00020 PMid:10362409

6. Celis R, Torres A, Gatell JM, Almela M, Rodríguez-Roisin $\mathrm{R}$, Agustí-Vidal A. Nosocomial pneumonia. A multivariate analysis of risk and prognosis. Chest. 1988;93(2):318-24. http://dx.doi.org/10.1378/chest.93.2.318 PMid:3338299

7. Chastre J, Trouillet JL, Vuagnat A, Joly-Guillou ML, Clavier H, Dombret MC, et al. Nosocomial pneumonia in patients with acute respiratory distress syndrome. Am J Respir Crit Care Med. 1998;157(4 Pt 1):1165-72. http:// dx.doi.org/10.1164/ajrccm.157.4.9708057 PMid:9563735

8. Sociedade Brasileira de Pneumologia e Tisiologia. Brazilian guidelines for treatment of hospital acquired pneumonia and ventilator associated pneumonia- 2007 [Article in Portuguese]. J Bras Pneumol. 2007;33(Suppl 1):S1-30. PMid:18833653 
9. Depuydt P0, Vandijck DM, Bekaert MA, Decruyenaere JM, Blot Sl, Vogelaers DP, et al. Determinants and impact of multidrug antibiotic resistance in pathogens causing ventilator-associated-pneumonia. Crit Care. 2008;12(6):R142. http://dx.doi.org/10.1186/cc7119 PMid:19014695 PMCid:2646301

10. Trouillet JL, Chastre J, Vuagnat A, Joly-Guillou ML, Combaux D, Dombret MC, et al. Ventilator-associated pneumonia caused by potentially drug-resistant bacteria. Am J Respir Crit Care Med. 1998;157(2):531-9. http:// dx.doi.org/10.1164/ajrccm.157.2.9705064 PMid:9476869

11. Zahar JR, Clec'h C, Tafflet M, Garrouste-Orgeas M, Jamali S, Mourvillier B, et al. Is methicillin resistance associated with a worse prognosis in Staphylococcus aureus ventilator-associated pneumonia? Clin Infect Dis. 2005;41(9):1224-31. http://dx.doi.org/10.1086/496923 PMid:16206094

12. Rello J, Torres A, Ricart M, Valles J, Gonzalez J, Artigas A, et al. Ventilator-associated pneumonia by Staphylococcus aureus. Comparison of methicillin-resistant and methicillin-sensitive episodes. Am J Respir Crit Care Med. 1994;150(6 Pt 1):1545-9. http://dx.doi.org/10.1164/ ajrccm.150.6.7952612 PMid:7952612

13. Sociedade Brasileira de Pneumologia e Tisiologia. Consenso Brasileiro de Pneumonias em Indivíduos Adultos Imunocompetentes. J Pneumol. 2001;27(Suppl 1):1-40.

14. Balthazar AB, Von Nowakonski A, De Capitani EM, Bottini PV, Terzi RG, Araújo S. Diagnostic investigation of ventilator-associated pneumonia using bronchoalveolar lavage: comparative study with a postmortem lung biopsy. Braz J Med Biol Res. 2001;34(8):993-1001. http://dx.doi.org/10.1590/S0100-879X2001000800004 PMid:11471037

15. Sader HS, Mendes RE, Gales AC, Jones RN, Pfaller MA, Zoccoli C, et al. Perfil de sensibilidade a antimicrobianos de bactérias isoladas do trato respiratório baixo de pacientes com pneumonia internados em hospitais brasileiros: resultados do Programa SENTRY, 1997 e 1998. J Pneumol. 2001;27(2):59-67. http://dx.doi. org/10.1590/S0102-35862001000200002

16. Carrilho CM. Fatores associados ao risco de desenvolvimento de pneumonia hospitalar na Unidade de Terapia Intensiva do Hospital Universitário Regional do Norte do Paraná, Londrina, PR. Rev Soc Bras Med Trop. 1999;32(4):455-6. http://dx.doi.org/10.1590/S0037-86821999000400021

17. Korn GP, Martino MD, Mimica IM, Mimica LJ, Chiavone PA, Musolino LR. High frequency of colonization and absence of identifiable risk factors for methicillin-resistant Staphylococcus aureus (MRSA) in intensive care units in Brazil. Braz J Infect Dis. 2001;5(1):1-7. http://dx.doi. org/10.1590/S1413-86702001000100001 PMid:11290308

18. Trouillet JL, Vuagnat A, Combes A, Kassis N, Chastre J, Gibert C. Pseudomonas aeruginosa ventilatorassociated pneumonia: comparison of episodes due to piperacillin-resistant versus piperacillin-susceptible organisms. Clin Infect Dis. 2002;34(8):1047-54. http:// dx.doi.org/10.1086/339488 PMid:11914992

19. Carmeli Y, Troillet N, Eliopoulos GM, Samore MH. Emergence of antibiotic-resistant Pseudomonas aeruginosa: comparison of risks associated with different antipseudomonal agents. Antimicrob Agents Chemother. 1999;43(6):1379-82. PMid:10348756 PMCid:89282
20. Harris AD, Perencevich E, Roghmann MC, Morris G, Kaye KS, Johnson JA. Risk factors for piperacillin-tazobactamresistant Pseudomonas aeruginosa among hospitalized patients. Antimicrob Agents Chemother. 2002;46(3):854-8. http://dx.doi.org/10.1128/AAC.46.3.854-858.2002 PMid:11850272 PMCid:127481

21. Kaminski C, Timsit JF, Dubois Y, Zahar JR, GarrousteOrgeas M, Vesin A, et al. Impact of ureido/carboxypenicillin resistance on the prognosis of ventilator-associated pneumonia due to Pseudomonas aeruginosa. Crit Care. 2011;15(2):R112. http://dx.doi.org/10.1186/cc10136 PMid:21481266 PMCid:3219393

22. Zavascki AP, Barth AL, Fernandes JF, Moro AL, Gonçalves AL, Goldani LZ. Reappraisal of Pseudomonas aeruginosa hospital-acquired pneumonia mortality in the era of metallo-beta-lactamase-mediated multidrug resistance: a prospective observational study. Crit Care. 2006;10(4):R114. http://dx.doi.org/10.1186/cc5006 PMid:16882337 PMCid:1751023

23. Furtado GH, Martins ST, Coutinho AP, Soares GM, Wey $\mathrm{SB}$, Medeiros EA. Incidence of vancomycin-resistant Enterococcus at a university hospital in Brazil [Article in Portuguese]. Rev Saude Publica. 2005;39(1):41-6. http://dx.doi.org/10.1590/S0034-89102005000100006 PMid:15654459

24. Paramythiotou E, Lucet JC, Timsit JF, Vanjak D, Paugam-Burtz C, Trouillet JL, et al. Acquisition of multidrug-resistant Pseudomonas aeruginosa in patients in intensive care units: role of antibiotics with antipseudomonal activity. Clin Infect Dis. 2004;38(5):670-7. http://dx.doi.org/10.1086/381550 PMid:14986251

25. Yu VL. Guidelines for hospital-acquired pneumonia and health-care-associated pneumonia: a vulnerability, a pitfall, and a fatal flaw. Lancet Infect Dis. 2011;11(3):24852. http://dx.doi.org/10.1016/S1473-3099(11)70005-6

26. Rodrigues PM, Carmo Neto Ed, Santos LR, Knibel MF. Ventilator-associated pneumonia: epidemiology and impact on the clinical evolution of ICU patients. J Bras Pneumol. 2009;35(11):1084-91. http://dx.doi.org/10.1590/ S1806-37132009001100005 PMid:20011843

27. Niederman MS. De-escalation therapy in ventilatorassociated pneumonia. Curr Opin Crit Care. 2006;12(5):452-7. http://dx.doi.org/10.1097/01. ccx.0000244126.84989.a2 PMid:16943725

28. Clec'h C, Timsit JF, De Lassence A, Azoulay E, Alberti C, Garrouste-Orgeas M, et al. Efficacy of adequate early antibiotic therapy in ventilator-associated pneumonia: influence of disease severity. Intensive Care Med. 2004;30(7):1327-33. http://dx.doi.org/10.1007/s00134004-2292-7 PMid:15197443

29. Micek ST, Ward S, Fraser VJ, Kollef MH. A randomized controlled trial of an antibiotic discontinuation policy for clinically suspected ventilator-associated pneumonia. Chest. 2004;125(5):1791-9. http://dx.doi.org/10.1378/ chest.125.5.1791 PMid:15136392

30. Kollef MH, Morrow LE, Niederman MS, Leeper KV, Anzueto A, Benz-Scott L, et al. Clinical characteristics and treatment patterns among patients with ventilatorassociated pneumonia. Chest. 2006;129(5):1210-8. Erratum in: Chest. 2006;130(1):308. http://dx.doi.org/10.1378/ chest.129.5.1210 PMid:16685011 


\section{About the authors}

\section{Renato Seligman}

Adjunct Professor. Department of Internal Medicine, Federal University of Rio Grande do Sul School of Medicine, Porto Alegre, Brazil.

\section{Luis Francisco Ramos-Lima}

Medical Student. Federal University of Rio Grande do Sul School of Medicine, Porto Alegre, Brazil.

\section{Vivian do Amaral Oliveira}

Medical Student. Federal University of Rio Grande do Sul School of Medicine, Porto Alegre, Brazil.

Carina Sanvicente

Medical Student. Federal University of Rio Grande do Sul School of Medicine, Porto Alegre, Brazil.

\section{Juliana Sartori}

Medical Student. Federal University of Rio Grande do Sul School of Medicine, Porto Alegre, Brazil.

\section{Elyara Fiorin Pacheco}

Medical Student. Federal University of Rio Grande do Sul School of Medicine, Porto Alegre, Brazil. 